\title{
The effect of pneumococcal immunization on total and antigen-specific $B$ cells in patients with severe chronic kidney disease
}

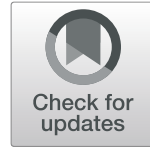

\author{
Gabrielle Nicole Gaultier ${ }^{1}$, William McCready ${ }^{2}$ and Marina Ulanova ${ }^{1,2^{*}}$
}

\begin{abstract}
Background: While the 23-valent pneumococcal polysaccharide vaccine (PPV23) is routinely used in Canada and some other countries to prevent pneumococcal infection in adults with chronic kidney disease (CKD), patients develop a suboptimal antibody response to PPV23 due to their immune dysfunction. The 13-valent pneumococcal conjugate vaccine (PCV13) has superior immunogenicity in some categories of immunocompromised adults; however, its effect on the immune response in CKD patients has only been addressed by two recent studies with conflicting results. The effect of PPV23 or PCV13 on B cells in these patients has not been previously studied. We studied the absolute numbers and proportions of B cells and subpopulations in two groups of adult patients with severe CKD pre- and 7 days post-immunization with PCV13: pneumococcal vaccine naïve and previously immunized with PPV23 (over one year ago).

Results: PPV23 immunized patients had significantly lower proportions and absolute numbers of class switched memory (CD19 + CD27 + IgM-), as well as lower absolute numbers of IgM memory $(C D 19+C D 27+$ lgM +$)$ and class switched B cells (CD19+CD27-IgM-) compared to PPV23 naïve patients. Following PCV13 immunization, the differences in absolute numbers of B-cell subpopulations between groups remained significant. The PPV23 immunized group had higher proportions of CD5- B cells along with lower proportions and absolute numbers of CD5+ B cells compared to PPV23 naïve patients both pre- and post-immunization with PCV13. However, previous PPV23 immunization did not have a noticeable effect on the numbers of total $\lg G$ or serotype $6 \mathrm{~B}$ and 14 specific antibody-secreting cells detected 7 days post-immunization with PCV13. Nevertheless, fold increase in anti-serotype 14 IgG concentrations 28 days post-PCV13 was greater in PPV23 naïve than in previously immunized patients.

Conclusions: The results suggest that immunization with PPV23 may result in long-term changes in B-cell subpopulations such as increased prevalence of CD5- B cells and decreased prevalence of class switched memory B cells in the peripheral blood. Because previous immunization with PPV23 in patients with CKD is associated with a significant decrease in the total class switched memory B cells in response to subsequent immunization with PCV13, this may reduce PCV13 immunogenicity in the setting of PPV23 followed by PCV13.
\end{abstract}

Trial registration: Registered February 24, 2015 at ClinicalTrials.gov (NCT 02370069).

Keywords: Chronic kidney disease (CKD), Streptococcus pneumoniae, B cells, Memory B cells, T-cell independent response, T-cell dependent response, 23-valent pneumococcal polysaccharide vaccine (PPV23), 13-valent pneumococcal conjugate vaccine (PCV13), Flow cytometry, Enzyme-linked immunospot assay (ELISPOT)

\footnotetext{
* Correspondence: mulanova@nosm.ca

${ }^{1}$ Department of Biology, Lakehead University, Thunder Bay, Canada

${ }^{2}$ Division of Medical Sciences, Northern Ontario School of Medicine,

Lakehead University, 955 Oliver Road, Thunder Bay, ON P7B 5E1, Canada
}

(c) The Author(s). 2019 Open Access This article is distributed under the terms of the Creative Commons Attribution 4.0 International License (http://creativecommons.org/licenses/by/4.0/), which permits unrestricted use, distribution, and reproduction in any medium, provided you give appropriate credit to the original author(s) and the source, provide a link to the Creative Commons license, and indicate if changes were made. The Creative Commons Public Domain Dedication waiver (http://creativecommons.org/publicdomain/zero/1.0/) applies to the data made available in this article, unless otherwise stated. 


\section{Background}

Chronic kidney disease (CKD) is a common condition which affects approximately $10-15 \%$ of adults globally [1]. Patients with the most advanced stages of this disease (severe CKD, or chronic renal failure) require lifesaving renal replacement therapy, such as hemodialysis or kidney transplantation [2,3]. Severe CKD is characterized by high mortality rates. Adjusted for age, sex, and race, the total mortality rate for patients with CKD as of 2018 was 103.0 per 1000 patient-years, more than double the total mortality rate for people without CKD [4]. Acute infections contribute substantially to the high rates of hospitalization and mortality in CKD patients, following only cardiovascular disease as a major cause of death [5]. High risk of septicaemia and other severe infections are attributed to both a compromised immune system and increased exposure to infectious agents in dialysis units [5-7].

Pneumococcus (Streptococcus pneumoniae) is a Grampositive, encapsulated diplococcus, which commonly colonizes the upper respiratory tract [8]. Upon breaching the host defences, the microorganism can cause mucosal (otitis media, sinusitis, pneumonia) and invasive (meningitis, septicaemia, pericarditis, etc.) infections $[9,10] . S$. pneumoniae is the most common cause of community acquired pneumonia (CAP) worldwide [11]. The highest incidence rates of CAP and invasive pneumococcal disease (IPD) are found in young children, elderly, and immunocompromised adults $[9,12]$. Patients with CKD, particularly those with nephrotic syndrome and undergoing dialysis, are highly susceptible to pneumococcal infection, especially pneumonia [13].

To prevent pneumococcal infection in adult patients with CKD, immunization with pneumococcal polysaccharide vaccine (PPV23), which contains purified capsular polysaccharides from 23 pneumococcal serotypes most commonly associated with IPD $(1,2,3,4,5,6 \mathrm{~B}, 7 \mathrm{~F}, 8,9 \mathrm{~N}$, $9 \mathrm{~V}, 10 \mathrm{~A}, 11 \mathrm{~A}, 12 \mathrm{~F}, 14,15 \mathrm{~B}, 17 \mathrm{~F}, 18 \mathrm{C}, 19 \mathrm{~F}, 19 \mathrm{~A}, 20,22 \mathrm{~F}$, $23 \mathrm{~F}$, and $33 \mathrm{~F}$ ), is currently recommended in Canada [14]. However, the effect of PPV23 in CKD patients is suboptimal because of their immune dysfunction $[15,16]$. The second-generation (polysaccharide-protein conjugate) vaccines, which induce $\mathrm{T}$-cell dependent antibody responses to polysaccharide antigens [17], have superior immunogenicity in immunocompromised adults and the elderly [18-20]. In Canada, 13-valent pneumococcal conjugate vaccine (PCV13), which consists of purified capsular polysaccharides of serotypes 1, 3, 4, 5, 6A, 6B, 7F, $9 \mathrm{~V}, 14,18 \mathrm{C}$, $19 \mathrm{~A}, 19 \mathrm{~F}$, and $23 \mathrm{~F}$ conjugated to a carrier protein $\left(\mathrm{CRM}_{197}\right)$, is recommended for several categories of immunocompromised adults, such as bone marrow transplantation recipients and HIV-infected individuals [21]. Although in some countries PCV13 is now used for immunization of patients with CKD, PCV13 immunogenicity in adults undergoing hemodialysis was only recently addressed by two studies with differing results. Mitra et al. (2016) showed that the antibody concentrations in patients with CKD declined significantly 12 months after immunization with PCV13, compared to 2 months post-immunization for 11 of the 13 serotypes tested [22]. Vandecasteele et al. (2018) demonstrated that immunization of CKD patients with PPV23 may have a negative effect on the immune response to PCV13 [23]. It was suggested that immunization with PPV23 could lead to depletion of memory B cells following exposure to purified polysaccharide antigens potentially affecting the development of antibody responses to polysaccharide antigens administered via protein-conjugate vaccines [24]. However, to the best of our knowledge, the effect of PPV23 or PCV13 on B cells in patients with CKD has not been previously studied. To address this question, we studied the proportions and numbers of B cells (CD19+), and their subpopulations: naïve (CD27-IgM+), IgM memory $(\mathrm{CD} 27+\mathrm{IgM}+)$, class switched $(\mathrm{CD} 27-\operatorname{IgM}-)$, class switched memory (CD27 + IgM-), CD5+ and CD5- B cells pre- and 7 days post-immunization with PCV13. Adult patients with severe CKD were separated into two groups: one group was pneumococcal vaccine naïve and the other group was previously immunized with PPV23 (over one year ago).

\section{Results}

In patients with severe CKD, immunization with PCV13 did not result in any significant changes in proportions of total B cells or any B-cell subpopulation except for CD5- cells. The CD19 + CD5- subpopulation increased on day 7 post-immunization $(74.2,68.5-$ $80.4 \%$ vs. $52.0,39.3-68.7 \%, p<0.05$, Table 1$)$. No significant changes in absolute numbers of total lymphocytes, B cells, or B-cell subpopulations assessed immediately prior to immunization and 7 days postimmunization were noticed (Additional file 1: Table S1). There was a statistically significant positive correlation between pre- and post-immunization absolute numbers of all tested cells, except for class switched and total B cells, and proportions of all cells with the exception of class switched and CD5- B cells (Additional file 2: Table S2).

To determine if PPV23 immunization had an impact on B-cell subpopulations, we tested the peripheral blood immediately prior to immunization with PCV13. The patients who had previously received PPV23 had significantly lower proportions (13.7, 9.2-20.3\% vs. $22.9,17.6-29.8, p<0.05$, Fig. $1 \mathrm{~A})$ and absolute numbers $\left(1.3,0.9-2.0 \times 10^{7}\right.$ cells/L vs. $2.6,1.8-3.8 \times 10^{7}$ cells $/ \mathrm{L}, p<0.05$, Fig. 1b) of class switched memory B cells, as well as lower absolute numbers of IgM memory (4.9, 3.1-7.5 X $10^{6}$ cells/L vs. 9.6, 6.3-1.5 X $10^{6}$ cells/ 
Table 1 B-cell subpopulations in patients with severe chronic kidney disease

\begin{tabular}{llll}
\hline B cells & Pre-immunization \% (Cl) & Post-immunization \% (Cl) & $p$ value \\
\hline Total B cells (CD19+) & $8.6(7.0-10.6)$ & $7.7(6.9-8.5)$ & $>0.05$ \\
Naïve (CD27-IgM+) & $46.3(38.8-55.3)$ & $42.5(36.7-49.3)$ & $>0.05$ \\
IgM memory (CD27+ IgM+) & $7.0(5.2-9.5)$ & $7.8(6.5-9.4)$ & $>0.05$ \\
Class Switched (CD27-lgM-) & $14.3(12.6-16.3)$ & $11.6(10.1-13.3)$ & $>0.05$ \\
Class Switched memory (CD27+lgM-) & $17.6(13.5-23.0)$ & $21.4(18-0-25.6)$ & $>0.05$ \\
CD19+ CD5+ & $30.2(23.9-38.1)$ & $24.9(19.7-31.5)$ & $>0.05$ \\
CD19+ CD5- & $52.0(39.3-68.7)$ & $74.2(68.5-80.4)$ & $<0.05$ \\
\hline
\end{tabular}

Immunophenotype of peripheral blood B cells was determined by flow cytometry pre- and 7 days post-immunization with PCV13. Geometric mean (GM) of proportions with $95 \%$ confidence intervals (Cl) are shown. For analysis of total B cells, naïve, lgM memory, class switched and class switched memory B cells, 33 pre-immunization and 60 post-immunization samples were studied. CD5 expression analysis, 33 pre-immunization and 39 post-immunization samples were studied. Statistical significance was determined by Mann-Whitney $\mathrm{U}$ test

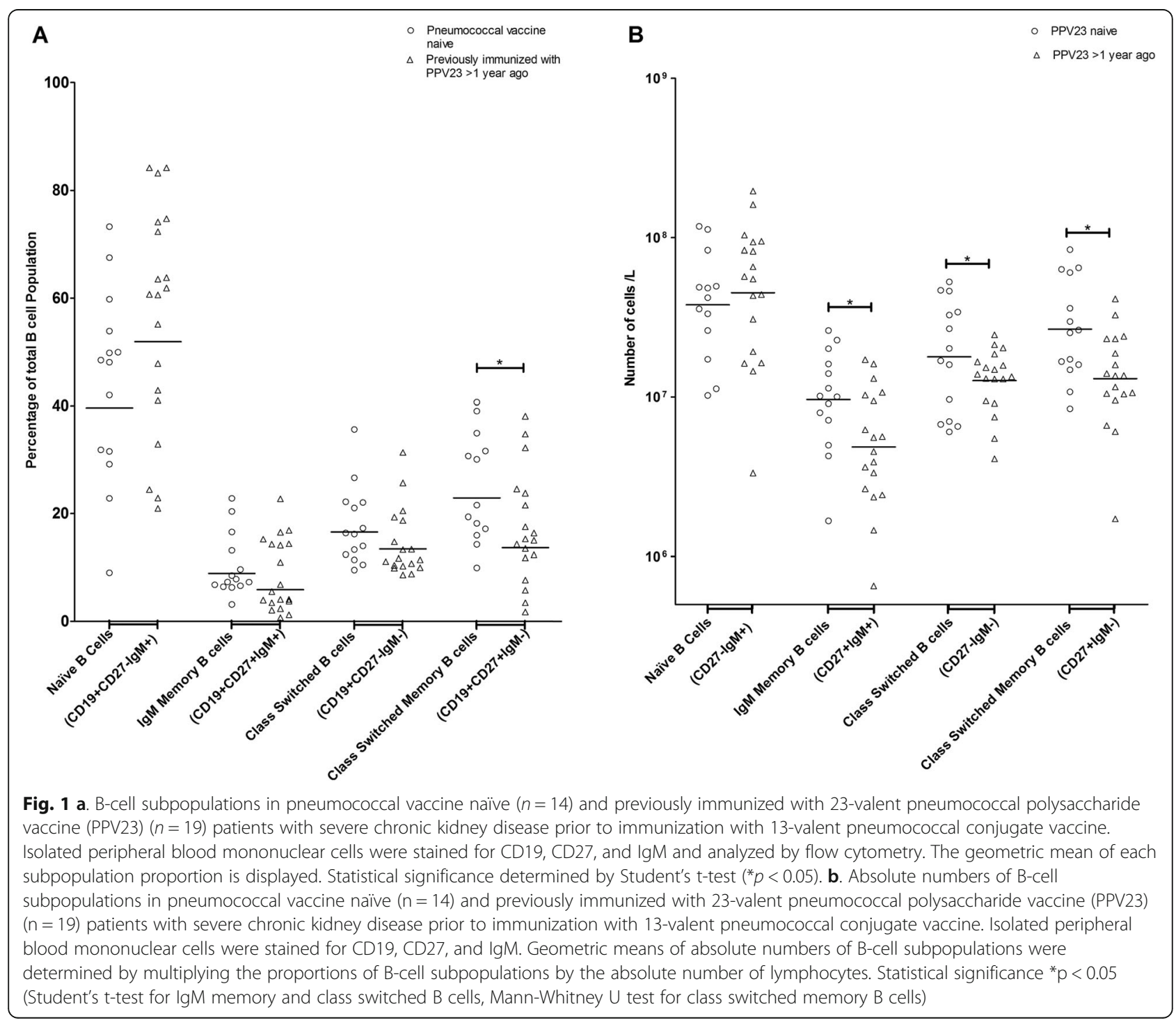


$\mathrm{L}, \mathrm{p}<0.05)$ and class switched B cells $\left(1.3,1.0-1.6 \times 10^{7}\right.$ cells/L vs. $1.8,1.8-4.1 \times 10^{7}$ cells $\left./ \mathrm{L}, \mathrm{p}<0.05\right)$ compared to PPV23 naïve patients (Fig. 1b). Previous immunization with PPV23 did not have a negative effect on total lymphocytes, as no significant difference in the absolute numbers of lymphocytes prior to PCV13 immunization was found between the groups $\left(1.0,0.8-1.4 \times 10^{9}\right.$ cells/ L vs. $0.9,0.8-1.1 \times 10^{9}$ cells/ L, $p>0.05$, Additional file 3: Table S3). However, PPV23 naïve patients had a slightly higher absolute number of $\mathrm{B}$ cells pre-immunization compared to PPV23 immunized patients $\left(9.9,7.0-13.9 \times 10^{7}\right.$ cells/ L vs. 8.3, 6.1-11.2 X $10^{7}$ cells/ L, p> 0.05, Additional file 3: Table S3).

Following the PCV13 immunization, the differences in absolute numbers of B-cell subpopulations between the groups remained significant. Those who had previously received PPV23 had lower numbers of IgM memory $\left(4.6,3.2-6.5 \times 10^{6}\right.$ cells/ L vs. 8.9, 5.7-14.0 $\mathrm{X} 10^{6}$ cells/ L, $\left.p<0.05\right)$, class switched B cells (1.2, $0.9-1.5 \times 10^{7}$ cells/ $\mathrm{L}$ vs. $1.6,1.0-2.7 \times 10^{7}$ cells/ $\mathrm{L}$, $\mathrm{p}<0.05)$, and class switched memory $\mathrm{B}$ cells (1.3, $0.9-2.0 \times 10^{7}$ cells/ L vs. 2.6, $1.8-3.8 \times 10^{7}$ cells/ L, $\mathrm{p}<0.05$ ) compared to PPV23 naïve patients (Fig. 2b), although no significant differences in proportions of B-cell subpopulations between the groups were detected (Fig. 2a). Both groups had the same absolute numbers of lymphocytes 7 days post-immunization (1.0, $0.7-1.3 \times 10^{9}$ cells/ L vs. $1.0,0.8-1.2 \times 10^{9}$ cells/ L, $p>0.05$, Additional file 3: Table S3). However, PPV23 naïve patients had slightly higher absolute numbers of total B cells compared to PPV23 immunized patients $\left(9.3,6.7-12.8 \times 10^{7}\right.$ cells/ L vs. 7.9, 5.7-10.9 X $10^{7}$ cells/ L, p > 0.05, Additional file 3: Table S3). The results suggest that previous immunization with PPV23 may decrease the numbers of IgM memory, class switched, and class switched memory B-cell subpopulations both pre- and 7 days post-immunization with PCV13.

As previous studies found an association between the CD5- subpopulation of B cells and production of IgG antibodies to pneumococcal polysaccharide antigens in response to PPV23 [25], we attempted to determine if there were any differences in CD5-expressing B cells between the groups with different histories of PPV23 vaccination. Prior to immunization with PCV13, those patients who had previously been immunized with PPV23 had higher proportion of CD5- (75.5, 70.6$80.6 \%$ vs. $37.5,20.6-68.3 \%, p<0.05)$ and lower proportion of CD5+ cells $(22.5,18.9-27.2 \%$ vs. 37.7, 24.1$58.86 \%, \mathrm{p}<0.05)$ as well as CD5+ absolute numbers $\left(2.1,1.6-2.8 \times 10^{7}\right.$ vs. $\left.3.5,2.0-6.0 \times 10^{7}, \mathrm{p}<0.05\right)$ compared to PPV23 naïve patients (Fig. 3a, b).

Seven days post-immunization with PCV13, patients previously immunized with PPV23 still had higher proportions of CD5- B cells $(69.5,55.7-86.9 \%$ vs. $37.4,18.9-73.66 \%, \mathrm{p}<0.05)$ and lower proportions $(16.9,13.9-20.6 \%$ vs. $35.2,23.0-53.7 \%, \mathrm{p}<0.05)$ and absolute numbers of CD5+ cells $\left(3.0,1.9-5.1 \times 10^{7}\right.$ cells/ L vs. $1.3,0.9-1.9 \times 10^{7}$ cells/ L, p < 0.05) compared to PPV23 naïve patients (Fig. 3a, b). Although higher absolute numbers of CD5- cells were present in PPV23 immunized than in PPV23 naive patients, the difference was not statistically significant (5.2, 3.3-8.1 X $10^{7}$ cells/ L vs. $3.5,1.6-7.7 \times 10^{7}$ cells/ L, $p>0.05$, Fig. 3b). These results show that immunization with PPV23 may lead to in an increased prevalence of the CD5- subpopulation among circulating B cells.

To determine if the numbers of total IgG and antigen specific antibody secreting cells (ASC) on day 7 postimmunization with PCV13 depend on previous immunization with PPV23, we conducted enzyme-linked immunospot (ELISPOT) assay on peripheral blood mononuclear cells (PBMC) stimulated with Staphylococcus aureus Cowan strain protein A (SAC) and CpG Oligonucleotide (ODN-2006). No statistically significant difference between PPV23 naïve and PPV23 immunized patients was found between the numbers of total IgG ASC (median \pm standard deviation) $(118.5 \pm 93.8$ vs. $151.0 \pm$ 93.5, $p>0.05$, Fig. 4a), ASC specific for pneumococcal polysaccharide serotype $6 \mathrm{~B}(0.5 \pm 0.34$ ASC vs. $0.5 \pm 0.36$ ASC), or serotype $14(1.0 \pm 0.5$ ASC vs. $0.8 \pm 0.3$ ASC, $p>0.05$, Fig. $4 \mathrm{~b}$ ). After outliers were removed, the number of patients that had antigen-specific IgG ASC below the limit of detection was calculated. There were 9/16 (56\%) PPV23 naïve and 16/25 (64\%) PPV23 immunized patients without detectable ASC specific for 6B; for serotype 14-specific ASC, the corresponding numbers were $7 /$ 16 (44\%) vs.13/25 (52\%), $p>0.05$ (Fisher's exact test). Hence, in this group of patients, previous PPV23 immunization did not have a noticeable effect on the numbers of total IgG ASC or serotype 6B and 14 specific ASC detected at day 7 post-immunization with PCV13.

To determine if previous immunization with PPV23 had an effect on the antibody response to PCV13, concentrations of pneumococcal 6B and 14 IgG antibodies were determined pre- and 28 days post-immunization (Additional file 4: Table S4). There were no significant differences between PPV23 naive and PPV23 immunized patients in the concentration of pneumococcal $6 \mathrm{~B}$ antibodies pre-immunization $(0.9,0.6-1.4 \mu \mathrm{g} / \mathrm{mL}$ vs. 1.1 , $0.7-1.6 \mu \mathrm{g} / \mathrm{mL}, p>0.05$ ) or post-immunization (2.1, $1.4-3.2 \mu \mathrm{g} / \mathrm{mL}$ vs. $2.4,1.4-3.9 \mu \mathrm{g} / \mathrm{mL}, \mathrm{p}>0.05)$. Compared to PPV23 immunized patients, PPV23 naive patients had a significantly lower concentration of pneumococcal 14 antibodies pre-immunization (2.1, $1.4-3.1 \mu \mathrm{g} / \mathrm{mL}$ vs. $2.4,1.4-3.9 \mu \mathrm{g} / \mathrm{mL}, p<0.05)$, but there was no significant difference in post-immunization 


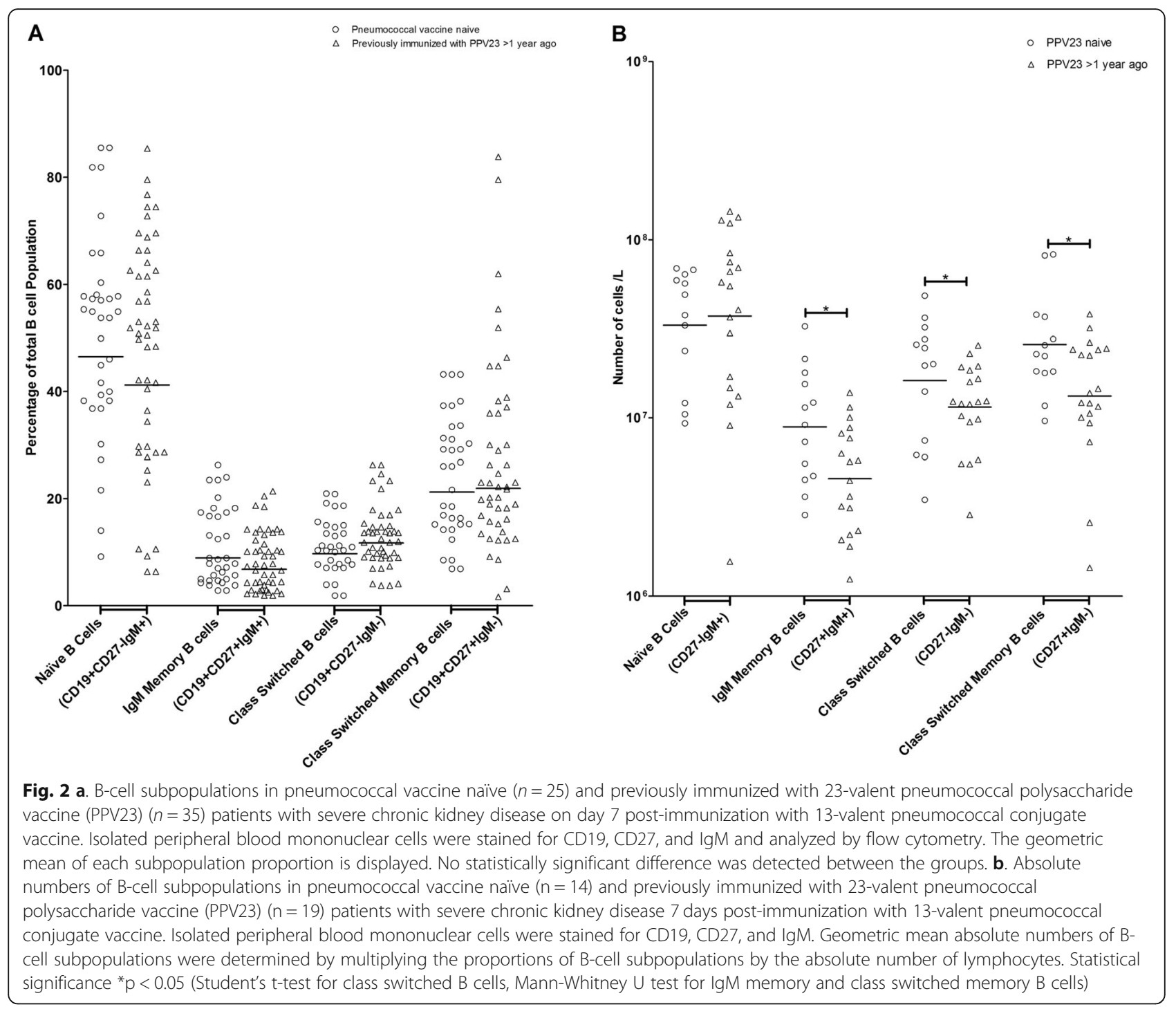

concentrations $(8.0,4.5-14.4 \mu \mathrm{g} / \mathrm{mL}$ vs. 8.1, 5.0-14.4, $p>0.05)$. When pre- and day 28 post-immunization concentrations were compared for each patient group, both groups had a significant increase in pneumococcal 6B antibody concentrations $(\mathrm{p}<0.05)$, however, only PPV23 naïve patients had a significant increase in pneumococcal 14 antibody concentrations $(p<0.01)$.

While PPV23 immunized patients had a slightly smaller fold change in pneumococcal $6 \mathrm{~B}$ antibodies compared to PPV23 naïve patients $(2.3,1.7-3.1 \mu \mathrm{g} / \mathrm{mL}$ vs. $2.8,1.8-4.3 \mu \mathrm{g} / \mathrm{mL}, \mathrm{p}>0.05)$, they had a significantly smaller fold change in pneumococcal 14 antibodies (1.3, $1.1-1.6 \mu \mathrm{g} / \mathrm{mL}$ vs. $1.9,1.3-2.8 \mu \mathrm{g} / \mathrm{mL}, \mathrm{p}<0.05)$. A strong negative correlation was found between the fold change of pneumococcal 14 antibodies and the preimmunization absolute numbers of CD5- B cells in PPV23 immunized patients $(\mathrm{r}=-0.8576, p<0.001$, Pearson correlation). No other significant correlation was detected between pre-immunization or day 7 postimmunization proportions or absolute numbers of CD5or class switched memory B-cell subpopulations and the fold change in pneumococcal $6 \mathrm{~B}$ or 14 antibody concentrations (data not shown). These results suggest that previous PPV23 immunization negatively affects the pneumococcal $6 \mathrm{~B}$ and 14 antibody response to subsequent immunization with PCV13 in patients with CKD.

\section{Discussion}

Although both types of pneumococcal vaccines induce the production of serotype-specific antibodies to $S$. pneumoniae capsular polysaccharides, PPV23 and PCV13 activate different immunological mechanisms. PPV23 contains purified capsular polysaccharides, which directly activate B cells in a T-cell independent manner. Bacterial capsular polysaccharides have multiple repeating epitopes which cross-link B cell receptors, causing 


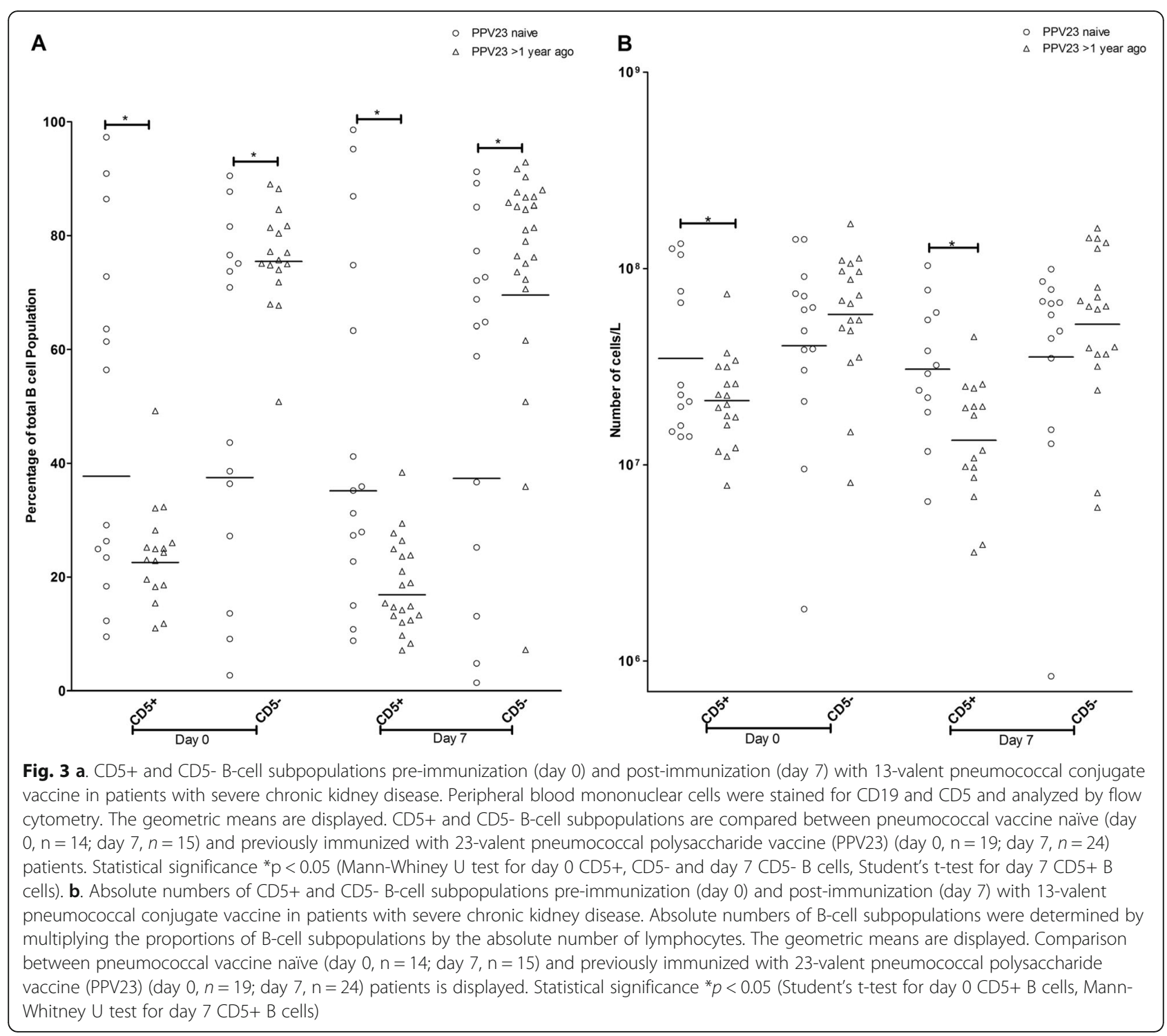

the activation of Bruton's tyrosine kinase that results in activation and proliferation of antigen-specific B cells [26]. The memory B cells generated from T-cell independent responses are short-lived and produce a less robust antibody response upon re-exposure to an antigen [27]. Vaccines containing capsular polysaccharides alone, such as PPV23, have poor immunogenicity in immunocompromised individuals [28]. In the case of PCV13, the conjugation of polysaccharides to $\mathrm{CRM}_{197}$, a non-toxic mutant of diphtheria toxin, which acts as a carrier protein, results in a T-cell dependent response. The protein-polysaccharide conjugate binds to B cell receptors and it is then brought into the endosome, where the protein component is processed into peptides and binds to the major histocompatibility complex class II (MHC II) molecules. Antigen presentation of the carrier protein in the context of MHC II results in the activation of
CD4+ $\mathrm{T}$ cells. The subsequent generation of signals stimulates B cell maturation, class switching, and proliferation resulting in the production of long-lived memory $B$ cells and secretion of polysaccharide-specific class switched high affinity antibodies [29].

It is still uncertain whether immunization with plain pneumococcal polysaccharide antigens (included into PPV23) negatively impacts antibody responses to subsequent immunization with polysaccharide-protein conjugate vaccines, such as PCV13. A study by Clutterbuck et al. (2012) measured the effect of PPV23 followed by the 7 -valent pneumococcal conjugate vaccine (PCV7) on antigen-specific B cells in older adults. It was found that while PCV7 immunization resulted in an increase in pneumococcal serotype-specific memory B cells, immunization with PPV23 depleted these cells and resulted in attenuated memory B cell responses [24]. No 


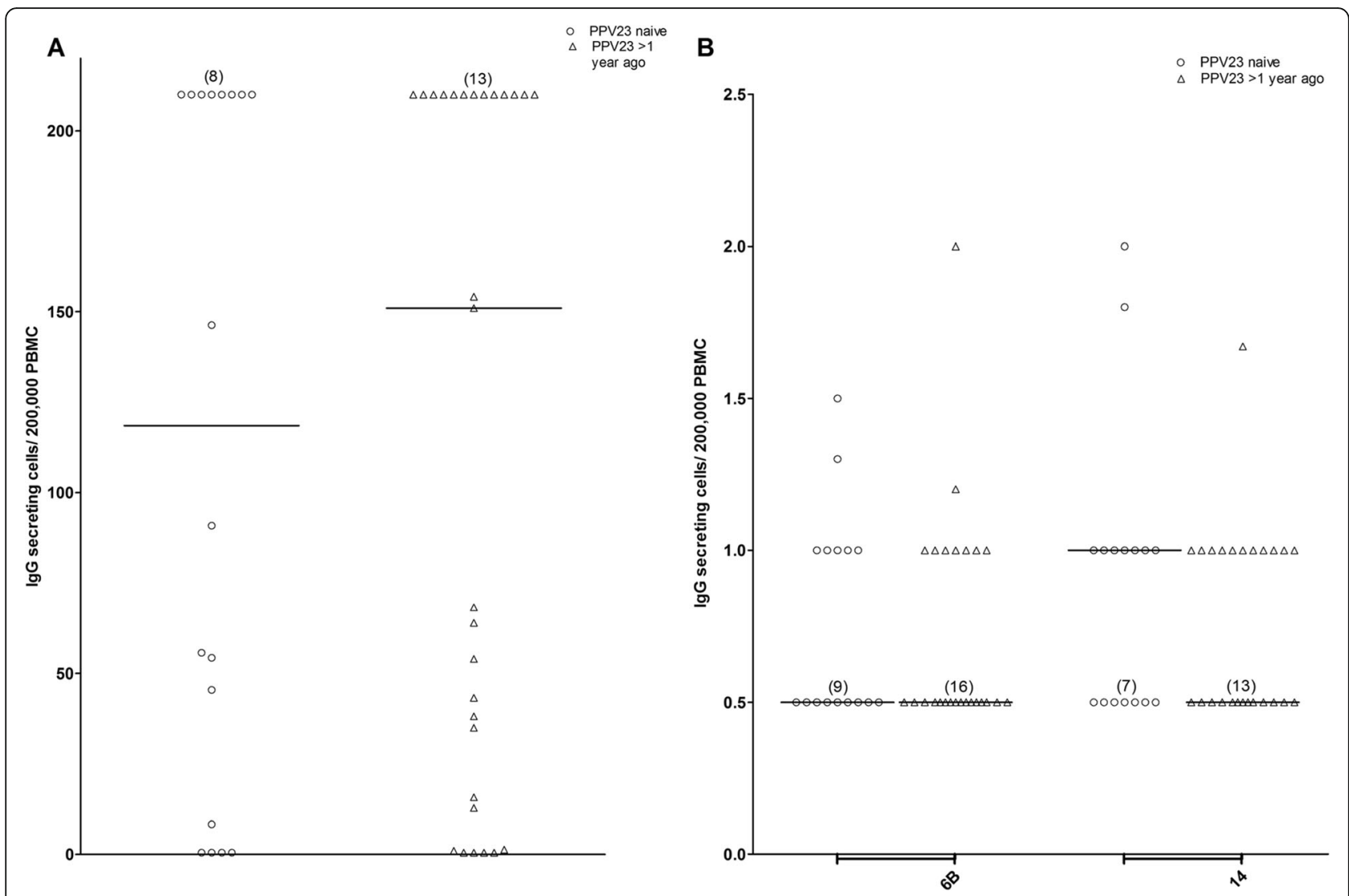

Fig. 4 a. Numbers of total lgG antibody secreting cells (ASC) per 200,000 peripheral blood mononuclear cells (PBMC) pneumococcal vaccine naïve $(n=18)$ and previously immunized with 23-valent pneumococcal polysaccharide vaccine (PPV23) ( $n=29)$ patients with severe chronic kidney disease on day 7 post-immunization with PCV13. The median is displayed counts above the upper limit of detection (200) were assigned a value of 210 (8 pneumococcal vaccine naive and 13 previously immunized with PPV23). If no spots were detected, a value of 0.5 was assigned for statistical purposes. PPV23 naive and PPV23 immunized each had 4 values below the limit of detection. Control wells coated with methylated human serum albumin were not displayed (all values were below the limit of detection). b. Numbers of IgG antibody secreting cells (ASC) specific for pneumococcal capsular polysaccharides of serotypes 6B or 14 per 200,000 peripheral blood mononuclear cell (PBMC) in pneumococcal vaccine naïve $(n=18)$ and previously immunized with 23-valent pneumococcal polysaccharide vaccine (PPV23) $(n=31)$ patients with severe chronic kidney disease 7 days post-immunization with PCV13 (median is shown). If no spots were detected a value of 0.5 was assigned for statistical purposes. For serotype 6B, 9 pneumococcal vaccine naïve and 16 previously immunized with PPV23 patients had ASC below the lower limit of detection. For serotype 14, 7 pneumococcal vaccine naïve and 13 previously immunized with PPV23 patients had ASC below the lower limit of detection. Control wells coated with methylated human serum albumin were not displayed (all below the limit of detection)

studies have assessed the effect of pneumococcal immunizations on B cells in patients with CKD. Vandecasteele et al. (2018) found that severe CKD patients previously immunized with PPV23 had lower antibody response to PCV13 compared to pneumococcal vaccine naïve patients [23]. Our results agree with this study, as PPV23 immunized patients had a slightly lower fold change in pneumococcal 6B IgG antibodies, and significantly lower fold change in pneumococcal 14 antibodies in response to PCV13 immunization. Recent studies assessed the effect of previous PPV23 immunization on the response to PCV13 or PCV7 in older adults found that previous immunization with PPV23 decreased antibody response to subsequent doses of PCV13 [20,30,31].
Patients with CKD are unique among other high-risk groups because they have multiple predisposing factors to pneumococcal infection, including uremia with its significant metabolic consequences, as well as the hemodialysis procedure, which causes premature aging of the immune system [6,32]. Patients with CKD also frequently have comorbidities, such as diabetes mellitus, which contribute to their immune dysfunction, and may receive immunosuppressive medications [33]. These patients also have increased exposure to infectious agents in the hospital environment. Multiple immune abnormalities such as decreased bactericidal ability of neutrophils, granulocyte and macrophage phagocytic function, defective function of antigen presenting cells, 
reduced numbers of $\mathrm{B}$ cells and decreased antibody producing capacity of plasma cells, increased T- and B-cell apoptosis, decreased thymic T-cell output, and impaired activation of $\mathrm{T}$-cell response have been found in CKD patients [34, 35].

Among immune abnormalities, this group has noticeable alterations in B cells and B-cell function. We have recently found that patients with CKD had decreased absolute numbers of B cells and B-cell subpopulations compared to healthy controls [36]. Pahl et al. (2010) also found decreased numbers of $B$ cells in CKD patients, suggesting that B-cell lymphopenia in patients with CKD was due to uremia [37]. It is possible that epigenetic changes caused by CKD affect the production of lymphoid cells at the hematopoietic stem cell level, resulting in decreased numbers of circulating $\mathrm{B}$ and $\mathrm{T}$ cells $[38,39]$.

In this study, we found that immunization with PPV23 may have a long-term effect on B-cell subpopulations in patients with CKD. Compared to vaccine naïve patients, PPV23 immunized patients of a similar age had significantly lower proportions of class switched memory B cells pre-immunization, and significantly lower absolute numbers of these cells both pre- and 7 days post-immunization with PCV13. In the literature, class switched memory B cells are defined as CD19+CD27+IgD- or CD19+ CD27 + IgM- cells $[40,41]$. These cells respond rapidly when re-exposed to the same antigen, resulting in the production of class switched, high affinity antibodies, and hence mediate long-lived humoral immunity [42, 43].

Although pneumococcal-specific B cells are only a small proportion of the total B cell population $(0.5 \%$ of the total B cell population pre-immunization and 2.02.75\% 7 days post-immunization with PPV23) [41], our results suggest that immunization with PPV23 results in a significant decrease of total class switched memory B cell population. This has not been previously reported as most studies focus on antigen-specific memory B cells. Chovancova et al. (2011) did not detect a significant change in the proportion or absolute number of class switched memory B cells defined as CD19+ CD27 + IgD-, between pre- and 7 days post-immunization with PPV23 in adults with common variable immunodeficiency (CVID) [44]. It is possible that immunization with pneumococcal polysaccharides results in polyclonal stimulation of B cells, leading to terminal differentiation of memory B cells followed by their depletion. Polyclonal stimulation of memory B cells, which causes their proliferation and differentiation into plasma cells, helps to maintain serological memory throughout life [45]. Polyclonal B cell activation by capsular polysaccharides of Neisseria meningitidis was previously reported by Oliveira et al. (1996) [46].

The role of CD5+ and CD5- B cells in humans is not completely understood. Due to the lack of somatic hypermutations in CD5+ B cells, it is thought that these cells are naïve B cells $[25,47]$. The expression of CD5 decreases with age and is associated with an increase in CD27 expression, indicating a shift in B-cell subpopulations towards an increase in the population of memory B cells [48]. A study by Moens et al. (2015) determined that after immunization with PPV23, ASC originating from CD5- B cells primarily produce pneumococcal anti-capsular polysaccharide IgG antibodies [25]. In agreement with this study, we found significantly higher proportions of CD5- B cells in PPV23 immunized patients compared to PPV23 naive ones. Hence immunization with PPV23 favors the generation of CD5- pneumococcal IgG memory B cells even in these immunocompromised adults. We found a strong negative correlation between the pre-immunization absolute numbers of CD5- B cells and the fold change of pneumococcal 14 IgG antibodies in PPV23 immunized patients. Hence, although previous immunization with PPV23 favours the generation of CD5- B cells, it has a negative effect on the antibody response to subsequent immunization with PCV13 in patients with CKD.

In an attempt to assess antigen-specific ASC, we used PBMC collected 7 days post immunization, given that ASC can be detected in the peripheral blood as early as 5 days after vaccination or infection and their numbers peak at day 7 [49]. The cells were stimulated with B-cell polyclonal activators, i.e. SAC, which induces crosslinking of surface immunoglobulins [50] and CpG ODN2006, which activates TLR 9 that stimulate the differentiation of memory B cells [51]. We measured the B-cell responses to pneumococcal capsular polysaccharides of serotypes $6 \mathrm{~B}$ and 14 because they have a significant impact on the global epidemiology of IPD [52].

As we detected only small numbers of ASC, this may reflect poor functional ability of $B$ cells from CKD patients to respond to polyclonal stimulation. In addition, capsular polysaccharides of serotypes $6 \mathrm{~B}$ and 14 have low immunogenicity [52]. As various modifications of ELISPOT exist, including different methods of B cell stimulation, it is difficult to compare our results to other studies. One study determined that the more doses of PPV23 asplenic adults with $\beta$-thalassemia received, the lower the amount of capsular polysaccharide-specific memory B cells in response to PCV13 was detected [53]. They also found that longer interval between PPV23 and PCV13 vaccinations was associated with greater numbers of antigen-specific memory B cells [53]. In that study, the range of capsular polysaccharide-specific IgG ASC per 1,000,000 PBMC was 0-24; in comparison, our patients had a maximum of two ASC specific to $6 \mathrm{~B}$ and 14 per 200,000 PBMC. Such discrepancies could be due to differences in age and immune abnormalities of participants. When we attempted to measure numbers of 
plasma cells using ELISPOT, no plasma cells specific for 6B or 14 were detected (data not shown). Similarly, in the study by Chovancova et al. (2011), CVID patients had no detectable IgG ASC specific for 23 pneumococcal capsular polysaccharides due to the lack of terminal B cell differentiation [44]. This could potentially explain the lack of B-cell response in CKD patients as it was demonstrated that such patients have decreased $B$ cell activating factor receptor expression in transitional B cells, resulting in their decreased survival [37].

Our study has several limitations, including small sample size that could contribute to lack of statistical significance in comparisons between groups. The patients received PPV23 at different times prior to PCV13 immunization (although always over 1 year before) that could contribute to the variability in results; we were unable to measure their immediate response to the PPV23 vaccine. Due to the large diversity among the CKD patients, we could not match our study participants for underlying conditions. We did not have healthy aged-matched controls that would have helped in the interpretation of responses by CKD patient groups. We were unable to calculate the fold change in antibody concentration for all participants due to sample collection issues such as participant withdrawal, etc. Our ongoing study of antigen-specific antibody responses in these two groups will aid in the clarification of the effect of previous immunization with PPV23 on $B$ cells and their ability to respond to subsequent immunization with PCV13. In addition, our work will help determine the longevity of the antibody response to PCV13 in patients with CKD.

\section{Conclusions}

Immunization with PPV23 may result in long-term changes in B-cell subpopulations such as an increased prevalence of CD5- B cells and decreased prevalence of class switched memory B cells in the peripheral blood. Because previous immunization with PPV23 in patients with CKD is associated with a significant decrease in the total class switched memory B cell population as well as a decreased pneumococcal antibody response to subsequent immunization with PCV13, this may reduce PCV13 immunogenicity in the setting of PPV23 followed by PCV13. Our findings emphasize the need for further studies to optimize pneumococcal immunization for adults with CKD.

\section{Methods}

\section{Patient recruitment and eligibility}

Sixty-one patients with stage 4 or 5 severe CKD (glomerular filtration rate (GFR), stage $4<30 \mathrm{~mL} / \mathrm{min} /$ $1.73 \mathrm{~m}^{2}$, stage $5<15 \mathrm{~mL} / \mathrm{min} / 1.73 \mathrm{~m}^{2}$ ) [54] who were receiving hemodialysis at the Thunder Bay Regional
Health Sciences Centre (TBRHSC) were recruited between May 2015 and August 2018. All the patients were over 18 years old, did not have a history of immunocompromising conditions, were not taking any immunosuppressive medications for more than 14 days in the past 6 months, and had not received any vaccines in the past month or blood transfusions in the past 3 months. Patients were separated into two groups: 25 PPV23 naïve patients (mean age 59 years, range $20-87$ years, $32 \%$ female) and 36 previously immunized with PPV23 $>1$ year ago (mean age 60 years, range $32-87$ years, $47 \%$ female). This study was registered at ClinicalTrials.gov (NCT 02370069) and approved by the research ethics boards of Lakehead University and TBRHSC.

\section{Immunization protocol and sample collection}

All patients received a single dose of PCV13 (Prevnar13, Pfizer, lots: H22520, J77978, M573833, M73833, R56653, and T24279) administered intramuscularly in the deltoid region during the dialysis procedure. Ten milliliters of peripheral blood for B-cell analysis were collected into BD Vacutainer ${ }^{\mathrm{m}}$ tubes with sodium heparin (BD Biosciences, Baltimore, MD, USA) immediately prior to immunization for flow cytometry analysis and 7 days post-immunization for flow cytometry and ELISPOT. Blood was collected for complete blood counts (CBC) just before immunization and day 7 post-immunization. An additional $10 \mathrm{~mL}$ of peripheral blood for serum antibody analysis was collected into BD Vacutainer ${ }^{\mathrm{Tm}}$ Venous Blood Collection Tubes: SST ${ }^{\mathrm{Tr}}$ Serum Separation Tubes: Hemogard (BD Biosciences) pre- and 28 days postimmunization, serum was stored at $-80^{\circ} \mathrm{C}$.

\section{Analysis of B cells}

PBMC were isolated by density gradient centrifugation using Lymphoprep (Stemcell Technologies, Vancouver, $\mathrm{BC}, \mathrm{CAN})$. Monocytes were removed using two consecutive incubations in RPMI 1640 medium with Lglutamine (Thermo Fisher Scientific, Mississauga, ON, CAN) supplemented with $1 \%$ antibiotic-antimicotic (Life Technologies, Burlington, ON, CAN) and $20 \%$ fetal bovine serum (FBS, Fisher Scientific, Whitby, ON, CAN) (20\% supplemented medium) in a BD Falcon ${ }^{\text {ma }} 100$ X 20 $\mathrm{mm}$ cell culture dish (Fisher Scientific) for $1 \mathrm{~h}$ at $37^{\circ} \mathrm{C}$, $5 \% \mathrm{CO}_{2}$. Non-adherent cells were washed with RPMI 1640 medium with L-glutamine supplemented with $1 \%$ antibiotic-antimicotic and 10\% FBS (10\% supplemented medium) and re-suspended at $2 \times 10^{6}$ cells/ $\mathrm{mL}$ in $10 \%$ supplemented medium. From the cell suspension, 200, 000 cells were immunostained with PE Mouse AntiHuman CD19, APC Mouse Anti-Human IgM, PerCP$\mathrm{Cy}^{\text {tm } 5.5}$ Mouse Anti-Human CD27, and FITC Mouse Anti-Human CD5 (BD Biosciences) at $4{ }^{\circ} \mathrm{C}$ for $1 \mathrm{~h}$. Samples were analyzed with BD FACSCalibur $^{\text {rm }}$ Flow 
Cytometer and CELLQUEST PRO software (BD Biosciences) to determine proportions of $\mathrm{B}$ cells $(\mathrm{CD} 19+)$ and subpopulations: naïve $(\mathrm{CD} 27-\operatorname{IgM}+)$, IgM memory $(\mathrm{CD} 27+\mathrm{IgM}+)$, class switched (CD27-IgM-), class switched memory (CD27 + IgM-), CD5+ and CD5- B cells as previously described [36]. Purity of CD19+ gated B cells was verified by counterstaining cells with FITC Mouse Anti-Human CD3 and PerCP-Cy ${ }^{\text {rx }} 5.5$ Mouse Anti-Human CD14 (BD Biosciences).

To determine the absolute numbers of $\mathrm{B}$ cells, a CBC was performed at the TBRHSC clinical lab. The absolute number of B cells was calculated by multiplying the percentage of CD19+ cells of the total gated lymphocyte population by the total lymphocyte count. The numbers of $B$ cell subpopulations were determined by multiplying the percentage of each subpopulation by the absolute number of B cells.

\section{Enzyme-linked immunospot (ELISPOT) assay Preparation of ELISPOT plates}

Multi-screen IP 96-well PVDF membrane filter plates (Millipore Canada Ltd., Etobicoke, ON, CAN) were coated with either goat anti-human IgG $(20 \mu \mathrm{g} / \mathrm{mL})$ (Cedarlane, Burlington, ON, CAN), or pneumococcal capsular polysaccharides of serotypes $6 \mathrm{~B}$, or $14(10 \mu \mathrm{g} /$ $\mathrm{mL}$ ) (Cedarlane) conjugated with methylated human serum albumin (mHSA, $10 \mu \mathrm{g} / \mathrm{mL}$ ) (National Institute for Biological Standards and Control, Hertfordshire, UK). Protocol for conjugation of the pneumococcal polysaccharides to mHSA for coating plates was provided by the Oxford Vaccine Group. Wells containing solution of mHSA $(10 \mu \mathrm{g} / \mathrm{mL})$ in PBS (Fisher Scientific) served as "no coating control". Plates were incubated at $37^{\circ} \mathrm{C}, 5 \% \mathrm{CO}_{2}$ for $5 \mathrm{~h}$ then stored at $4{ }^{\circ} \mathrm{C}$ overnight. The next day, plates were washed with PBS then blocked with $2 \%$ skim milk (Thermo Fisher Scientific) in PBS for $3 \mathrm{~h}$ at room temperature. The plate was washed again with PBS before cells were added.

\section{Detection of memory B cells}

Following removal of monocytes, $2 \times 10^{6}$ PBMC were plated in a 6-well plate in $10 \%$ supplemented medium with SAC $(5 \mu \mathrm{g} / \mathrm{mL})$ (Sigma Aldrich, Oakville ON, CAN) ODN-2006 $(3 \mu \mathrm{g} / \mathrm{mL})$ (Cedarlane, Burlington, ON, CAN). After 6 days of stimulation at $37^{\circ} \mathrm{C}, 5 \% \mathrm{CO}_{2}$, the cells were harvested, washed with $10 \%$ supplemented medium, re-suspended in the same medium and counted. Cells were plated at 200,000 cells per well in the 96 -well coated plate at $37^{\circ} \mathrm{C}, 5 \% \mathrm{CO}_{2}$ for $18 \mathrm{~h}$. After the incubation, the plate was washed using PBS with 0.01\% Tween 20 (Fisher Scientific) before the HRP conjugated mouse anti-human IgG was added $(0.13 \mu \mathrm{g} / \mathrm{mL})$ (Hybridoma Reagent Laboratory, Baltimore, MD, USA) for $2 \mathrm{~h}$ at room temperature. To visualize the spots, KPL
TrueBlue $^{\mathrm{Tn}}$ Peroxidase Substrate (Mandel Scientific, Guelph, ON, CAN) was added for $10 \mathrm{~min}$ and then washed for $5 \mathrm{~min}$ with distilled water. After washing, the plate was left to dry for a minimum of 1 day. Once dry, the spots were visualized using $2 \mathrm{X}$ magnification (Nikon Eclipse 80i).

\section{ELISPOT counting}

To determine the numbers of ASC, two lab members counted the spots per well individually, and a mean of the counts was calculated. Counts over 200 were considered above detection limits and assigned a value of 210; counts of 0 were assigned a value of 0.5 for statistical purposes.

\section{Enzyme-linked immunosorbent assay (ELISA)}

Amounts of IgG anti-pneumococcal $6 \mathrm{~B}$ and 14 antibodies were quantified using the ELISA protocol provided by the World Health Organization [55].

\section{Statistical analysis}

Statistical analysis was performed using Graph-Pad Prism 5 (GraphPad Prism Software Inc., San Diego, CA). The geometric means for the percentage of each B-cell subpopulation, absolute numbers of B cells, concentration, and fold change of antibody concentration with 95\% confidence intervals (CI) and the medians of ASC with standard deviation were calculated. Outliers were identified and removed prior to statistical analysis [56]. Groups were compared either using a Student's t-test or Mann-Whitney $U$ test, and correlation analyses performed using Pearson or Spearman analysis based on the distribution of the data. A $p$ value of $<0.05$ was reported as statistically significant.

\section{Supplementary information}

Supplementary information accompanies this paper at https://doi.org/10. 1186/s12865-019-0325-9.

Additional file 1: Table S1. Absolute numbers of lymphocytes and B cells in patients with severe chronic kidney disease. Absolute numbers of lymphocytes and B cells (geometric means, GM with 95\% confidence intervals, $\mathrm{Cl}$ ) in 33 patients with severe chronic kidney disease pre- and 7 days post-immunization with PCV13. Absolute numbers of B cells were determined by multiplying the proportion of CD19+ peripheral blood mononuclear cells by the absolute number of lymphocytes obtained via complete blood counts.

Additional file 2: Table S2. Correlation of absolute numbers and proportions of B cells and B-cell subpopulations pre- and 7 days postimmunization. Correlation between pre- and post-immunization absolute numbers or proportions of total B cells (CD19+), naïve (CD27-lgM+), IgM memory $(C D 27+\lg M+)$, class switched (CD27-lgM-), class switched memory (CD27 + lgM), CD5+ and CD5- B cells.

Additional file 3: Table S3. Absolute numbers of lymphocytes and B cells in patients with severe chronic kidney disease that are pneumococcal vaccine naïve or previously immunized with PPV23 > 1 year ago. Absolute numbers of lymphocytes and B cells (geometric means, GM with 95\% confidence intervals, CI) in severe chronic kidney 
disease patients that are pneumococcal vaccine naive $(n=14)$ or previously immunized with PPV23 $>1$ year ago $(n=19)$ pre- and 7 days post-immunization with PCV13.

Additional file 4: Table S4. Concentrations and fold change of pneumococcal $6 \mathrm{~B}$ and $14 \mathrm{lgG}$ antibodies pre- and 28 days postimmunization. Geometric mean concentration (GMC) with 95\% confidence intervals $(\mathrm{Cl})$ in severe chronic kidney disease patients who are pneumococcal vaccine naïve $(n=22)$ or previously immunized with PPV23 > 1 year ago $(n=34)$ pre- and 28 days post-immunization with PCV13. The fold change represents the response to PCV13 immunization. * compares day 0 pre-immunization and day 28 post-immunization antibody concentrations for each serotype and patient group, + compares the pre-immunization concentrations between patient groups, \# compares the fold change for each serotype between groups. Statistical significance determined by Mann- Whitney $U$ test, ${ }^{*} p<0.05$, ${ }^{* *} p<0.01$.

\section{Abbreviations}

ASC: antibody secreting cells; CBC: complete blood count; Cl: confidence intervals; CKD: chronic kidney disease; ELISA: enzyme-linked immunosorbent assay; ELISPOT: Enzyme-linked immunospot assay; MHC II: Major histocompatibility complex class II; mHSA: methylated human serum albumin; ODN: CpG Oligonucleotide (ODN-2006); PBMC: Peripheral blood mononuclear cells; PCV13: 13-valent pneumococcal conjugate vaccine; PCV7: 7-valent pneumococcal conjugate vaccine; PPV23: 23-valent pneumococcal polysaccharide vaccine; SAC: Staphylococcus aureus Cowan strain protein $\mathrm{A}$

\section{Acknowledgements}

We would like to thank all the study participants for donating blood for our study, as well as the nurses at the Renal Services (TBRHSC) for collecting samples from patients. We thank Eli Nix, Angele Desbiens-Forget (Northern Ontario School of Medicine) and Lori Moon (Clinical Trials Department, TBRHSC) for assistance with patient recruitment. We thank Kylie Williams for helping with development of methodology, as well as Amanda Bakke and Brenda Huska for counting the ELISPOT plates. We also thank Angele Desbiens-Forget and Brenda Huska for performing ELISA experiments.

\section{Authors' contributions}

MU and WM conceived and supervised the study; GNG recruited participants and collected samples, optimized and performed all B cell experiments, analyzed the data and drafted the manuscript; MU substantially revised the manuscript draft. All authors reviewed the results and text and approved the final version of the manuscript

\section{Funding}

This study was supported by Pfizer (Investigator-initiated research project) and Northern Ontario Academic Medicine Association (grants A-14-10 and A17-06 from the AHSC AFP Innovation fund).

The funders had no role in the data collection and analysis, decision to publish or preparation of the manuscript.

\section{Availability of data and materials}

The datasets used and/or analysed during the current study are available from the corresponding author on reasonable request.

\section{Ethics approval and consent to participate}

This study was approved by the research ethics boards of Lakehead University (approval reference number: 085 14-15) and the Thunder Bay Regional Health Sciences Centre (approval reference number: 2014124). Written informed consent was obtained from each participant prior to determination of eligibility.

\section{Consent for publication}

Not applicable.

\section{Competing interests}

Pfizer provided funding for the study and was the supplier of the PCV13 vaccine used for the study.
Received: 7 August 2019 Accepted: 30 October 2019

Published online: 12 November 2019

\section{References}

1. Levin A, Tonelli M, Bonventre J, Coresh J, Donner JA, Fogo AB, et al. Global kidney health 2017 and beyond: a roadmap for closing gaps in care, research, and policy. Lancet. 2017 Oct 21;390(10105):1888-917. PubMed PMID: 28434650. Pubmed Central PMCID. . https://doi.org/10.1016/S01406736(17)30788-2.

2. Andrassy KM. Comments on 'KDIGO 2012 clinical practice guideline for the evaluation and Management of Chronic Kidney Disease'. Kidney Int. 2013 Sep;84(3):622-3. PubMed PMID: 23989362. Pubmed Central PMCID. . https:// doi.org/10.1038/ki.2013.243.

3. Webster AC, Nagler EV, Morton RL, Masson P. Chronic kidney disease. Lancet. 2017 mar 25;389(10075):1238-52. PubMed PMID: 27887750. Pubmed Central PMCID. . https://doi.org/10.1016/S0140-6736(16)32064-5.

4. System USRD. 2018 USRDS annual data report: epidemiology of kidney disease in the United States. 2018 [available from: https://www.usrds.org/2 018/view/v1_03.aspx.

5. Naqvi SB, Collins AJ. Infectious complications in chronic kidney disease. Adv chronic kidney dis. 2006 Jul;13(3):199-204. PubMed PMID: 16815225 Pubmed Central PMCID. . https://doi.org/10.1053/j.ackd.2006.04.004.

6. Vaziri ND, Pahl MV, Crum A, Norris K. Effect of uremia on structure and function of immune system. J Ren Nutr 2012 Jan;22(1):149-156. PubMed PMID: 22200433. Pubmed Central PMCID: PMC3246616. doi:https://doi.org/ 10.1053/j.jrn.2011.10.020.

7. Ravani P, Palmer SC, Oliver MJ, Quinn RR, MacRae JM, Tai DJ, et al. Associations between hemodialysis access type and clinical outcomes: a systematic review. J Am Soc Nephrol 2013 Feb;24(3):465-473. PubMed PMID: 23431075. Pubmed Central PMCID: PMC3582202. doi:https://doi.org/ 10.1681/ASN.2012070643.

8. Henriques-Normark B, Tuomanen El. The pneumococcus: epidemiology, microbiology, and pathogenesis. Cold Spring Harb Perspect Med. 2013 Jul; 1 3(7). PubMed PMID: 23818515. Pubmed Central PMCID: PMC3685878. Epub 2013/07/03. https://doi.org/10.1101/cshperspect.a010215.

9. Drijkoningen JJ, Rohde GG. Pneumococcal infection in adults: burden of disease. Clin Microbiol infect. 2014 may;20 Suppl 5:45-51. PubMed PMID: 24313448. Pubmed Central PMCID. . https://doi.org/10.1111/1469-0691. 12461.

10. Simell B, Auranen K, Kayhty H, Goldblatt D, Dagan R, O'Brien KL, et al. The fundamental link between pneumococcal carriage and disease. Expert rev vaccines. 2012 Jul;11(7):841-55. PubMed PMID: 22913260. Pubmed Central PMCID. . https://doi.org/10.1586/erv.12.53.

11. Remington LT, Sligl WI. Community-acquired pneumonia. Curr Opin Pulm med. 2014 may;20(3):215-24. PubMed PMID: 24614242. Pubmed Central PMCID. . https://doi.org/10.1097/MCP.0000000000000052.

12. Jain S, Self WH, Wunderink RG, Fakhran S, Balk R, Bramley AM, et al. Community-acquired pneumonia requiring hospitalization among U.S. adults. N Engl J Med 2015 Jul 30;373(5):415-427. PubMed PMID: 26172429. Pubmed Central PMCID: PMC4728150. doi:https://doi.org/10.1056/ NEJMoa1500245.

13. Viasus D, Garcia-Vidal C, Cruzado JM, Adamuz J, Verdaguer R, Manresa F, et al. Epidemiology, clinical features and outcomes of pneumonia in patients with chronic kidney disease. Nephrol dial transplant. 2011 Sep;26(9): 2899-906. PubMed PMID: 21273232. Pubmed Central PMCID. . https://doi. org/10.1093/ndt/gfa798

14. Government of Canada PHC. Canadian Immunization Guide: Part 3Vaccination of Specific populations 2015 [Available from: https://www. canada.ca/en/public-health/services/publications/healthy-living/canadianimmunization-guide-part-3-vaccination-specific-populations/page-7immunization-persons-with-chronic-diseases.html\#p3c6t1.

15. Mahmoodi M, Aghamohammadi A, Rezaei N, Lessan-Pezeshki M, Pourmand G, Mohagheghi MA, et al. Antibody response to pneumococcal capsular polysaccharide vaccination in patients with chronic kidney disease. Eur cytokine Netw. 2009 Jun;20(2):69-74. PubMed PMID: 19541592. Pubmed Central PMCID. . https://doi.org/10.1684/ecn.2009.0153.

16. Pourfarziani $V$, Ramezani MB, Taheri S, Izadi M, Einollahi B. Immunogenicity of pneumococcal vaccination in renal transplant recipients and hemodialysis patients: a comparative controlled trial. Ann transplant. 2008; 13(3):43-7. PubMed PMID: 18806734. Pubmed Central PMCID. 
17. Stein KE. Thymus-independent and thymus-dependent responses to polysaccharide antigens. J infect dis. 1992 Jun;165 Suppl 1:S49-52. PubMed PMID: 1588177. Pubmed Central PMCID. . https://doi.org/10.1093/infdis/165supplement_1-s49.

18. Lee KY, Tsai MS, Kuo KC, Tsai JC, Sun HY, Cheng AC, et al. Pneumococcal vaccination among HIV-infected adult patients in the era of combination antiretroviral therapy. Hum Vaccin Immunother. 2014;10(12):3700-3710. PubMed PMID: 25483681. Pubmed Central PMCID: PMC4514044. doi:https:// doi.org/10.4161/hv.32247.

19. Shiramoto M, Hanada R, Juergens C, Shoji Y, Yoshida M, Ballan B, et al. Immunogenicity and safety of the 13-valent pneumococcal conjugate vaccine compared to the 23-valent pneumococcal polysaccharide vaccine in elderly Japanese adults. Hum Vaccin Immunother 2015;11(9):2198-2206. PubMed PMID: 26176163. Pubmed Central PMCID: PMC4635730. doi:https:// doi.org/10.1080/21645515.2015.1030550.

20. Jackson LA, Gurtman A, Rice K, Pauksens K, Greenberg RN, Jones TR, et al. Immunogenicity and safety of a 13-valent pneumococcal conjugate vaccine in adults 70 years of age and older previously vaccinated with 23-valent pneumococcal polysaccharide vaccine. Vaccine. 2013 Aug 2;31(35):3585-93. PubMed PMID: 23688527. Pubmed Central PMCID. . https://doi.org/10.1016/ j.vaccine.2013.05.010.

21. Government of Canada PHC. Page 16: Canadian Immunization Guide: Part 4- Active Vaccines 2016 [Available from: https://www.canada.ca/en/publichealth/services/publications/healthy-living/canadian-immunization-guidepart-4-active-vaccines/page-16-pneumococcal-vaccine.html

22. Mitra S, Stein GE, Bhupalam S, Havlichek DH. Immunogenicity of 13-Valent conjugate pneumococcal vaccine in patients 50 years and older with endstage renal disease and on Dialysis. Clin Vaccine Immunol 2016 Nov;23(11): 884-887. PubMed PMID: 27581438. Pubmed Central PMCID: PMC5098022. doi:https://doi.org/10.1128/CVI.00153-16.

23. Vandecasteele SJ, De Bacquer D, Caluwe R, Ombelet S, Van Vlem B. Immunogenicity and safety of the 13-valent pneumococcal conjugate vaccine in 23-valent pneumococcal polysaccharide vaccine-naive and preimmunized patients under treatment with chronic haemodialysis: a longitudinal quasi-experimental phase IV study. Clin Microbiol infect. 2018 Jan;24(1):65-71. PubMed PMID: 28559003. Pubmed Central PMCID. . https:// doi.org/10.1016/j.cmi.2017.05.016.

24. Clutterbuck EA, Lazarus R, Yu LM, Bowman J, Bateman EA, Diggle L, et al. Pneumococcal conjugate and plain polysaccharide vaccines have divergent effects on antigen-specific B cells. J Infect Dis 2012 May 1;205(9):1408-1416. PubMed PMID: 22457293. Pubmed Central PMCID: PMC3324398. doi:https:// doi.org/10.1093/infdis/jis212.

25. Moens L, Verbinnen B, Covens K, Wuyts G, Johnson M, Roalfe L, et al. Antipneumococcal capsular polysaccharide antibody response and CD5 B lymphocyte subsets. Infect Immun 2015 Jul;83(7):2889-2896. PubMed PMID: 25939510. Pubmed Central PMCID: PMC4468564. doi:https://doi.org/10. 1128/IAI.00068-15.

26. Vos Q, Lees A, Wu ZQ, Snapper CM, Mond JJ. B-cell activation by T-cellindependent type 2 antigens as an integral part of the humoral immune response to pathogenic microorganisms. Immunol rev. 2000 Aug;176:15470. PubMed PMID: 11043775. Pubmed Central PMCID.

27. Defrance T, Taillardet M, Genestier L. T cell-independent B cell memory. Curr Opin Immunol. 2011 Jun;23(3):330-6. PubMed PMID: 21482090. Pubmed Central PMCID. https://doi.org/10.1016/j.coi.2011.03.004.

28. Papadatou I, Spoulou V. Pneumococcal vaccination in high-risk individuals: are we doing it right? Clin Vaccine Immunol. 2016 May;23(5):388-95. PubMed PMID: 27009210. Pubmed Central PMCID: PMC4860474. Epub 2016/03/25. https://doi.org/10.1128/CVl.00721-15.

29. Avci FY, Kasper DL. How bacterial carbohydrates influence the adaptive immune system. Annu rev Immunol. 2010;28:107-30. PubMed PMID: 19968562. Pubmed Central PMCID. . https://doi.org/10.1146/annurevimmunol-030409-101159.

30. Greenberg RN, Gurtman A, Frenck RW, Strout C, Jansen KU, Trammel J, et al. Sequential administration of 13-valent pneumococcal conjugate vaccine and 23-valent pneumococcal polysaccharide vaccine in pneumococcal vaccine-naive adults 60-64 years of age. Vaccine. 2014 Apr 25;32(20):236474. PubMed PMID: 24606865. Pubmed Central PMCID. . https://doi.org/10. 1016/j.vaccine.2014.02.002.

31. Lazarus R, Clutterbuck E, Yu LM, Bowman J, Bateman EA, Diggle L, et al. A randomized study comparing combined pneumococcal conjugate and polysaccharide vaccination schedules in adults. Clin infect dis. 2011 mar 15;
52(6):736-42. PubMed PMID: 21367726. Pubmed Central PMCID. . https://doi. org/10.1093/cid/cir003.

32. Kato S, Chmielewski M, Honda H, Pecoits-Filho R, Matsuo S, Yuzawa Y, et al. Aspects of immune dysfunction in end-stage renal disease. Clin J Am Soc Nephrol 2008 Sep;3(5):1526-1533. PubMed PMID: 18701615. Pubmed Central PMCID: PMC4571158. doi:https://doi.org/10.2215/CJN.00950208.

33. Geerlings SE, Hoepelman Al. Immune dysfunction in patients with diabetes mellitus (DM). FEMS Immunol med Microbiol. 1999 Dec;26(3-4):259-65. PubMed PMID: 10575137. Pubmed Central PMCID. . https://doi.org/10.1111/ j.1574-695X.1999.tb01397.x

34. Syed-Ahmed M, Narayanan M. Immune dysfunction and risk of infection in chronic kidney disease. Adv chronic kidney dis. 2019 Jan;26(1):8-15. PubMed PMID: 30876622. Pubmed Central PMCID. . https://doi.org/10.1053/j.ackd. 2019.01.004

35. Castelo-Branco C, Soveral I. The immune system and aging: a review. Gynecol Endocrinol. 2014 Jan;30(1):16-22. PubMed PMID: 24219599. Pubmed Central PMCID. . https://doi.org/10.3109/09513590.2013.852531.

36. Gaultier GN, McCready W, Ulanova M. Natural immunity against Haemophilus influenzae type a and B-cell subpopulations in adult patients with severe chronic kidney disease. Vaccine. 2019 May 20. PubMed PMID: 31122854. Pubmed Central PMCID. doi:https://doi.org/10.1016/j.vaccine. 2019.05.036

37. Pahl MV, Gollapudi S, Sepassi L, Gollapudi P, Elahimehr R, Vaziri ND. Effect of end-stage renal disease on B-lymphocyte subpopulations, IL-7, BAFF and BAFF receptor expression. Nephrol Dial Transplant 2010 Jan;25(1):205-212. PubMed PMID: 19684120. Pubmed Central PMCID: PMC2796898. doi:https:// doi.org/10.1093/ndt/gfp397.

38. Freitas GRR, da Luz Fernandes M, Agena F, Jaluul O, Silva SC, Lemos FBC, et al. Aging and End Stage Renal Disease Cause A Decrease in Absolute Circulating Lymphocyte Counts with A Shift to A Memory Profile and Diverge in Treg Population. Aging Dis. 2019 Feb;10(1):49-61. PubMed PMID: 30705767. Pubmed Central PMCID: PMC6345336. doi:https://doi.org/10. 14336/AD.2018.0318

39. Betjes MG, Litjens $\mathrm{NH}$. Chronic kidney disease and premature ageing of the adaptive immune response. Curr Urol rep. 2015 Jan;16(1):471. PubMed PMID: 25404185. Pubmed Central PMCID. . https://doi.org/10.1007/s11934014-0471-9.

40. Berron-Ruiz L, Lopez-Herrera G, Avalos-Martinez CE, Valenzuela-Ponce C, Ramirez-SanJuan E, Santoyo-Sanchez G, et al. Variations of B cell subpopulations in peripheral blood of healthy Mexican population according to age: relevance for diagnosis of primary immunodeficiencies. Allergol Immunopathol (Madr). 2016 Nov - Dec;44(6):571-9. PubMed PMID: 27780620. Pubmed Central PMCID. Epub 2016/10/27. https://doi.org/10. 1016/j.aller.2016.05.003.

41. Khaskhely N, Mosakowski J, Thompson RS, Khuder S, Smithson SL, Westerink MA. Phenotypic analysis of pneumococcal polysaccharide-specific B cells. J Immunol 2012 Mar 1;188(5):2455-2463. PubMed PMID: 22271652. Pubmed Central PMCID: PMC3288481. doi:https://doi.org/10.4049/jimmunol.1102809.

42. Inoue T, Moran I, Shinnakasu R, Phan TG, Kurosaki T. Generation of memory B cells and their reactivation. Immunol rev. 2018 may;283(1):138-49. PubMed PMID: 29664566. Pubmed Central PMCID. . https://doi.org/10.1111/imr. 12640.

43. Kurosaki T, Kometani K, Ise W. Memory B Cells. Nat rev Immunol. 2015 mar; 15(3):149-59. PubMed PMID: 25677494. Pubmed Central PMCID. doi:https:// doi.org/10.1038/nri3802.

44. Chovancova Z, Vlkova M, Litzman J, Lokaj J, Thon V. Antibody forming cells and plasmablasts in peripheral blood in CVID patients after vaccination. Vaccine. 2011 may 31;29(24):4142-50. PubMed PMID: 21473955. Pubmed Central PMCID. . https://doi.org/10.1016/j.vaccine.2011.03.087.

45. Bernasconi NL, Traggiai E, Lanzavecchia A. Maintenance of serological memory by polyclonal activation of human memory B cells. Science. 2002 Dec 13;298(5601):2199-202. PubMed PMID: 12481138. Pubmed Central PMCID. . https://doi.org/10.1126/science.1076071.

46. Oliveira TG, Milani SR, Travassos LR. Polyclonal B-cell activation by Neisseria meningitidis capsular polysaccharides elicit antibodies protective against Trypanosoma cruzi infection in vitro. J Clin lab anal. 1996;10(4):220-8. PubMed PMID: 8811466. Pubmed Central PMCID. . https://doi.org/10.1002/ (SICI)1098-2825(1996)10:4<220::AID-JCLA8>3.0.CO;2-D.

47. Brezinschek HP, Foster SJ, Brezinschek RI, Dorner T, Domiati-Saad R, Lipsky $\mathrm{PE}$. Analysis of the human $\mathrm{VH}$ gene repertoire. Differential effects of selection and somatic hypermutation on human peripheral CD5(+)/lgM+ 
and CD5(-)/lgM+ B cells. J Clin Invest 1997;99(10):2488-2501. PubMed PMID: 9153293. Pubmed Central PMCID: PMC508090. doi:https://doi.org/10. 1172/JCl119433.

48. Barrett DJ, Sleasman JW, Schatz DA, Steinitz M. Human anti-pneumococcal polysaccharide antibodies are secreted by the CD5- B cell lineage. Cell Immunol. 1992 Aug;143(1):66-79. PubMed PMID: 1377990. Pubmed Central PMCID.

49. Saletti G, Cuburu N, Yang JS, Dey A, Czerkinsky C. Enzyme-linked immunospot assays for direct ex vivo measurement of vaccine-induced human humoral immune responses in blood. Nat Protoc. 2013 Jun;8(6): 1073-87. PubMed PMID: 23660756. Pubmed Central PMCID. . https://doi.org/ 10.1038/nprot.2013.058.

50. Kozlowski LM, Kunning SR, Zheng Y, Wheatley LM, Levinson Al. Staphylococcus aureus Cowan I-induced human immunoglobulin responses: preferential IgM rheumatoid factor production and VH3 mRNA expression by protein A-binding B cells. J Clin Immunol. 1995 may;15(3):14551. PubMed PMID: 7559917. Pubmed Central PMCID.

51. Jahnmatz M, Kesa G, Netterlid E, Buisman AM, Thorstensson R, Ahlborg N. Optimization of a human IgG B-cell ELISpot assay for the analysis of vaccine-induced B-cell responses. J Immunol methods. 2013 may 31;391(12):50-9. PubMed PMID: 23454005. Pubmed Central PMCID. . https://doi.org/ 10.1016/j.jim.2013.02.009

52. Rodriguez ME, van den Dobbelsteen GP, Oomen LA, de Weers O, van Buren $\mathrm{L}$, Beurret M, et al. Immunogenicity of Streptococcus pneumoniae type 6B and 14 polysaccharide-tetanus toxoid conjugates and the effect of uncoupled polysaccharide on the antigen-specific immune response. Vaccine. 1998 Dec;16(20):1941-9. PubMed PMID: 9796048. Pubmed Central PMCID. Epub 1998/10/31.

53. Papadatou I, Piperi C, Alexandraki K, Kattamis A, Theodoridou M, Spoulou V. Antigen-specific B-cell response to 13-valent pneumococcal conjugate vaccine in asplenic individuals with beta-thalassemia previously immunized with 23-valent pneumococcal polysaccharide vaccine. Clin infect dis. 2014 Sep 15;59(6):862-5. PubMed PMID: 24879786. Pubmed Central PMCID. https://doi.org/10.1093/cid/ciu409.

54. Levin A, Hemmelgarn B, Culleton B, Tobe S, McFarlane P, Ruzicka M, et al. Guidelines for the management of chronic kidney disease. CMAJ. 2008 Nov 18:179(11):1154-1162. PubMed PMID: 19015566. Pubmed Central PMCID: PMC2582781. doi:https://doi.org/10.1503/cmaj.080351.

55. Laboratories WHOPSR. Training manual for Enzyme linked immunosorbent assay for the quantitation of Streptococcus pneumoniae serotype specific lgG (Pn Ps ELISA). [Available from: https://www.vaccine.uab.edu/uploads/mdocs/ ELISAProtocol(007sp).pdf.

56. William Mendenhall RB, Barbara Beaver, S. Ahmed. Introduction to Probability and Statistics (3rd Canadian Edition): Nelson Education; 2014

\section{Publisher's Note}

Springer Nature remains neutral with regard to jurisdictional claims in published maps and institutional affiliations.

Ready to submit your research? Choose BMC and benefit from:

- fast, convenient online submission

- thorough peer review by experienced researchers in your field

- rapid publication on acceptance

- support for research data, including large and complex data types

- gold Open Access which fosters wider collaboration and increased citations

- maximum visibility for your research: over $100 \mathrm{M}$ website views per year

At $\mathrm{BMC}$, research is always in progress.

Learn more biomedcentral.com/submissions 